\title{
Analysis of the Need for State Junior High School Teachers in Purwakarta District in 2020
}

\author{
Aries Rapelianto*, Udin Syaefudin Sa'ud \\ Educational Administration Program \\ Universitas Pendidikan Indonesia \\ Bandung, Indonesia \\ *ariesrapelianto@gmail.com, usaud@upi.edu
}

\begin{abstract}
This study aims to describe the needs of SMP Negeri teachers in Purwakarta District in 2020 so that a description of their needs can be found. This research is a descriptive study with a quantitative approach method. The subjects of this study were State Junior High School teachers in Purwakarta Regency with a total population of 378 people in 10 schools. The research location is in Purwakarta District with data collection at the Purwakarta Regency Education Office. The location was chosen because the Purwakarta District area is the area with the largest population in Purwakarta Regency. The data method is a secondary documentation study. The data analysis technique used is mathematical equations. The results of research on the need for ideal junior high school teachers in Purwakarta Regency in $\mathbf{2 0 2 0}$ show that there is still a shortage of 73 teachers in natural science, social science, mathematics, religion and manner education, and cultural arts subjects. In addition, there are surplus of 69 teachers in the subjects of Indonesian language, English, sports and health physical education, Pancasila and citizenship education, and Sundanese language. The needs of teachers for certain subjects can temporarily be overcome by hiring non-PNS teachers with appropriate qualifications so that they can be funded by budgets originating from the APBN (BOS) and funds sourced from the APBD. Another solution is the surplus distribution of subject teachers to be distributed to state junior high schools in need.
\end{abstract}

Keywords-the needs of teachers, state junior high school teachers, mathematical equations, shortage of teachers, surplus of teachers

\section{INTRODUCTION}

Based on Law Number 17 of 2007 concerning the LongTerm National Development Plan for 2005-2025, it explains that health and education development has an important role in improving the quality of human resources. The challenges faced in education development include: 1) providing quality education services to increase the proportion of the population completing basic education to a higher level of education. 2) reducing the number of illiterate people. 3 ) as well as reducing the fairly high level of education gap between community groups, including between the rich and the poor, between urban and rural residents, between people in developed and underdeveloped areas, and between genders. 4) improving the quality and relevance, including reducing the gap in the quality of education between regions, between sexes, and between rich and poor people so that educational development can play a role in encouraging national development as a whole including in developing national pride, noble character, the ability to live in a multicultural society, as well as increasing competitiveness [1].

There are supporting factors that are very important to education development, namely the availability of teachers both in quality and quantity. Sunuyeko et al [2] gives out assume, the availability of adequate teachers faces two main problems, namely meeting the need for teachers that are not in accordance with regional needs and improving professional quality that does not meet minimum standards. These two problems create a high disparity in the number of teacher needs in various regions in Indonesia.

Good planning is needed so that the distribution of teachers in each takes place optimally, so that there is no shortage of teachers in one area but on the other hand there is a build-up in other areas. Education management is aimed at ensuring: 1) community access to adequate, equitable and affordable education services. 2) the quality and competitiveness of education and its relevance to the needs and / or conditions of society. 3) effectiveness, efficiency and accountability of education management [3].

Referring to the Decree of the Minister of State Apparatus Empowerment number KEP/ 75/ M.PAN/ 7/2004, the analysis of employee needs is a process that is carried out logically, regularly and continuously to determine the number and quality of employees required. The employee needs analysis is carried out so that employees have a clear job so that employees can be seen clearly contributing to the achievement of the mission of the organization or program that has been set [4]

Based on data from the Purwakarta Regency Education Office, there are 378 Middle School subject teachers in Purwakarta District, with the following composition in table 1: 
TABLE I. TEACHER OF JUNIOR HIGH SCHOOL IN PURWAKARTA DISTRICT

\begin{tabular}{|l|l|l|}
\hline \multirow{2}{*}{ No. } & \multicolumn{2}{|c|}{ Teacher Availability Data } \\
\cline { 2 - 3 } & \multicolumn{1}{|c|}{ Subject } & Amount \\
\hline 1. & Indonesian Language & 53 \\
\hline 2. & English & 41 \\
\hline 3. & Natural Science & 49 \\
\hline 4. & Social Science & 42 \\
\hline 5. & Mathematic & 43 \\
\hline 6. & Religion and Manner Education & 30 \\
\hline 7. & Sports and Health Physical Education & 31 \\
\hline 8. & Pancasila and Citizenship Education & 27 \\
\hline 9. & Craft & 18 \\
\hline 10. & Cultural Arts & 25 \\
\hline 11. & Local Content (Sundanese Language) & 19 \\
\hline
\end{tabular}

This research was conducted to determine the compatibility between the data on subject teachers of State Junior High Schools in Purwakarta District with the Basic and Secondary Education Process Standards as regulated in the Regulation of the Minister of Education and Culture Number 22 of 2016 [5].

TABLE II. NUMBER OF UNIT CLASSES

\begin{tabular}{|l|l|l|l|}
\hline No. & Education Unit & \multicolumn{1}{|c|}{$\begin{array}{c}\text { Number of } \\
\text { classes }\end{array}$} & $\begin{array}{c}\text { Maximum Number } \\
\text { of Students per } \\
\text { Class }\end{array}$ \\
\hline 1. & SD/MI & 53 & 53 \\
\hline 2. & SMP/MTs & 41 & 41 \\
\hline 3. & SMA/MA & 49 & 49 \\
\hline 4. & SMK & 42 & 42 \\
\hline 5. & SDLB & 43 & 43 \\
\hline 6. & SMPLB & 30 & 30 \\
\hline 7. & SMALB & 31 & 31 \\
\hline
\end{tabular}

\section{MEthodS}

\section{A. Type of Research}

This research is a descriptive analytic study using a quantitative approach method. Quantitative research methods can be interpreted as a research method based on the philosophy of positivism, used to examine a particular population or sample, sampling techniques are generally carried out randomly, data collection uses research instruments, data analysis is quantitative/statistical in order to test the hypothesis has been established [6]

The nature of research has been stated by many experts, for qualitative research scientific paradigm is used (scientific paradigm) [7]. In quantitative research, the steps in processing scientific knowledge are carried out by combining empirical rational thinking, namely by building a connecting bridge in the form of hypothesis submission. This hypothesis serves as a temporary answer to the problems studied in scientific activities [7].

\section{B. Research Place}

This research was conducted at the Purwakarta Regency Education Office from August to September 2020. The research location is in Purwakarta District with data collection at the Purwakarta Regency Education Office. The location was chosen because the Purwakarta District area is the area with the largest population in Purwakarta Regency.

\section{Object of Research}

The research object was 378 teachers of State Junior High Schools in Purwakarta District, both PNS and Non PNS with undergraduate qualifications (S1).

\section{Data Analysis Technique}

The data used in this study include the number of State Junior High School students, the number of study groups, and the number of teachers of State Junior High Schools in Purwakarta District. The data was obtained based on data recapitulation from the Purwakarta Regency Education Office in 2020. To process the data in this study, a mathematical equation approach was used. The mathematical equation formula refers to the Decree of the Minister for Empowerment of State Apparatus Number KEP / 75 / M.PAN / 7/2004 concerning Guidelines for Calculating Employee Needs Based on Workload in the Context of Compiling the Formation of Civil Servants [4].

Based on these regulations, the following formulations are obtained [4]:

$$
J G M P=\frac{J R B \times W}{24}
$$

Explanation:

JGMP = number of subject teachers

JRB = number of classes

$\mathrm{W}=$ allocation of time per week

$24=$ the number of hours of compulsory teaching per week [4].

The workload of teaching personnel is regulated in Law Number 14 of 2005 concerning Teachers and Lecturers in article 35 paragraphs (1) and (2) which states that 1) the workload of teachers includes main activities, namely planning learning, implementing learning, assessing learning outcomes, guide and train students, and carry out additional tasks. 2) The teacher workload as referred to in paragraph (1) is at least 24 (twenty four) hours of face-to-face and a maximum of 40 (forty) face-to-face hours in 1 (one) week [8].

\section{RESULTS AND DISCUSSION}

The problems of the Purwakarta Regency in the education sector as stated in the Regional Medium-Term Development Plan 2018-2023 are as follows:

- The education accessibility for the community not evenly distributed, especially for the secondary education. 
- The quality of education services is not yet optimal and the relevance of education to the working world is still low.

- The unequal availability of quality educational facilities and infrastructure at all levels.

- Unequal distribution of educators and education personnel and competencies that still need to be improved at all levels of education.

- The brawl among student increasingly rampant [9].

In accordance with the first mission in the 2018-2023 Regional Medium-Term Development Plan, namely "Improving the Quality of Education, Health and Social Welfare", this mission contains an understanding of improving the quality of human resources as a series of efforts to realize the whole human being and the whole Purwakarta community which includes development. human, both as a human being and as a development resource which is an inseparable unit [9].

Departing from this, it takes synergy between local government policies in the field of human resources, both in terms of procurement and maintenance, so that the objectives of the Purwakarta Regency Government's mission can be realized.

The need for secondary school subject teachers in Purwakarta is calculated using a mathematical equation formula to get the ideal teacher needs referring to the Decree of the Minister for State Apparatus Empowerment Number KEP / 75 / M.PAN/7/2004 regarding Guidelines for Calculating Employee Needs Based on Workload in Formation. Government employees. The data used is data sourced from the 2020 Simdapodik.

The subject teachers referred to in the research are Indonesian Language Teachers, English Teachers, Natural Science Teachers, Social Science Teachers, Mathematics Teachers, Sundanese Language Teachers (local content), Religion and Character Education Teachers, Sport and Health Physical Education Teachers, Pancasila and Citizenship Education Teachers, Craft Teachers, and Cultural Arts Teachers.

\section{A. Discussion}

The problem of meeting the needs of teachers is not only a problem for Purwakarta Regency, but is a common problem for the world of education in Indonesia. The teacher retirement rate cannot be matched by the provision of teachers, especially in the same subjects coupled with a reduction in the quota for the appointment of civil servant teachers (PNS) by the government. The policy for the procurement of civil servant human resources is a policy of the central government, so that local governments cannot make optimal efforts in the procurement of teachers for this reason.

Based on data from the Purwakarta Regency Education Office, there are 10 State Junior High Schools (SMP) in Purwakarta Regency, with the following details:
TABLE III. L LIST OF STATE JUNIOR HIGH SCHOOL IN PURWAKARTA DISTRICT

\begin{tabular}{|l|l|l|}
\hline \multicolumn{1}{|c|}{ No. } & \multicolumn{1}{|c|}{ List of State } & \multicolumn{1}{c|}{ Village/ Sub-District } \\
\hline 1. & SMP Negeri 1 Purwakarta & Nagrikidul \\
2. & SMP Negeri 2 Purwakarta & Ciseureuh \\
3. & SMP Negeri 3 Purwakarta & Nagritengah \\
4. & SMP Negeri 4 Purwakarta & Nagritengah \\
5. & SMP Negeri 5 Purwakarta & Ciseureuh \\
6. & SMP Negeri 6 Purwakarta & Sindangkasih \\
7. & SMP Negeri 7 Purwakarta & Nagrikaler \\
8. & SMP Negeri 8 Purwakarta & Cipaisan \\
9. & SMP Negeri 9 Purwakarta & Citalang \\
10. & SMP Negeri 10 Purwakarta & Ciseureuh \\
\hline
\end{tabular}

Based on the calculations, the following results were obtained:

TABLE IV. DATA ON THE NEEDS OF STATE JUNIOR HigH SCHOOL TEACHER IN PURWAKARTA DISTRICT

\begin{tabular}{|c|c|c|c|}
\hline \multirow{2}{*}{ No. } & \multicolumn{3}{|c|}{ The Needs of Teacher } \\
\hline & Subjects & Shortage & Surplus \\
\hline 1. & Indonesian Language & - & 30 \\
\hline 2. & English & - & 18 \\
\hline 3. & Natural Science & 17 & - \\
\hline 4. & Social Science & 24 & - \\
\hline 5. & Mathematic & 23 & - \\
\hline 6. & Religion and Manner Education & 4 & - \\
\hline 7. & $\begin{array}{l}\text { Sports and Health Physical } \\
\text { Education }\end{array}$ & - & 7 \\
\hline 8. & $\begin{array}{l}\text { Pancasila and } \quad \text { Citizenship } \\
\text { Education }\end{array}$ & - & 8 \\
\hline 9. & Craft & - & 4 \\
\hline 10. & Cultural Arts & 5 & - \\
\hline 11. & $\begin{array}{l}\text { Local Content } \quad \text { (Sundanese } \\
\text { Language) }\end{array}$ & - & 2 \\
\hline
\end{tabular}

\section{B. The Needs for Subject Teacher in Purwakarta District}

1) The needs of indonesian language teachers: In general, there are surplus of 30 Indonesian Language Subject Teachers in Purwakarta District, with the following details:

- There is surplus each of 4 Indonesian Language Teachers at SMP Negeri 1 Purwakarta, SMP Negeri 2 Purwakarta, and SMP Negeri 3 Purwakarta.

- There is surplus each of 2 Indonesian Language Teachers at SMP Negeri 4 Purwakarta, SMP Negeri 8 Purwakarta, and SMP Negeri 10 Purwakarta.

- There are surplus of 5 Indonesian Language Teachers at SMP Negeri 5 Purwakarta.

- There are surplus of 3 Indonesian Language Teachers each at SMP Negeri 6 Purwakarta and SMP Negeri 7 Purwakarta.

- There is surplus of 1 Indonesian Language Teacher at SMP Negeri 9 Purwakarta.

2) The needs of english teachers: There are surplus of 18 SMP English Subject Teachers in Purwakarta District, with the following details: 
- There is surplus each of 1 English teacher at SMP Negeri 1 Purwakarta, SMP Negeri 4 Purwakarta, SMP Negeri 6 Purwakarta, SMP Negeri 9 Purwakarta, and SMP Negeri 10 Purwakarta.

- There are 4 more English teachers at SMP Negeri 2 Purwakarta.

- There are surplus of 2 English teachers each at SMP Negeri 3 Purwakarta, SMP Negeri 5 Purwakarta, and SMP Negeri 8 Purwakarta.

- There are 3 more English teachers at SMP Negeri 7 Purwakarta.

3) The needs of natural science teachers: As many as 17 Junior High School Natural Science Subject Teachers are needed in the Purwakarta District, with the following details:

- It takes as many as 4 Natural Science Teachers at SMP Negeri 1 Purwakarta.

- It takes 1 natural science teacher each at SMP Negeri 2 Purwakarta, SMP Negeri 5 Purwakarta, SMP Negeri 6 Purwakarta, SMP Negeri 8 Purwakarta, SMP Negeri 9 Purwakarta and SMP Negeri 10 Purwakarta.

- It takes 3 Natural Science Teachers at SMP Negeri 3 Purwakarta.

- It takes 2 Natural Science Teachers each at SMP Negeri 4 Purwakarta and SMP Negeri 7 Purwakarta.

4) The needs of social science teachers: As many as 24 Junior High School Social Science Subject Teachers are needed in Purwakarta District, with the following details:

- It takes 3 social science teachers each at SMP Negeri 1 Purwakarta, SMP Negeri 2 Purwakarta, SMP Negeri 4 Purwakarta, and SMP Negeri 8 Purwakarta.

- It takes as many as 4 Social Science Teachers at SMP Negeri 3 Purwakarta.

- It takes 2 Social Science Teachers each at SMP Negeri 5 Purwakarta, SMP Negeri 7 Purwakarta, and SMP Negeri 10 Purwakarta.

- It takes 1 Social Science teacher each at SMP Negeri 6 Purwakarta and SMP Negeri 9 Purwakarta.

5) The needs of mathematics teachers: It takes 23 Junior High School Mathematics Teachers in Purwakarta District, with the following details:

- It takes 3 Mathematics Teachers each at SMP Negeri 1 Purwakarta, SMP Negeri 5 Purwakarta, and SMP Negeri 9 Purwakarta.

- It takes 2 Mathematics Teachers each at SMP Negeri 2 Purwakarta, SMP Negeri 8 Purwakarta and SMP Negeri 10 Purwakarta.

- It takes 5 Mathematics Teachers at SMP Negeri 3 Purwakarta.
- It takes 1 Mathematics teacher each at SMP Negeri 4 Purwakarta, SMP Negeri 6 Purwakarta and SMP Negeri 7 Purwakarta.

6) The needs of sundanese language teachers (local content): It takes as many as 4 Junior High School Sundanese Language Subject Teachers in Purwakarta District, with the following details:

- The need for Sundanese Language Teachers at SMP Negeri 1 Purwakarta, SMP Negeri 2 Purwakarta, SMP Negeri 4 Purwakarta, SMP Negeri 7 Purwakarta, SMP Negeri 8 Purwakarta, and SMP Negeri 10 Purwakarta is sufficient.

- It takes 1 Sundanese language teacher each at SMP Negeri 3 Purwakarta, SMP Negeri 5 Purwakarta, SMP Negeri 6 Purwakarta, and SMP Negeri 9 Purwakarta.

7) The needs of Islamic religion and manner education teachers: There are surplus of 7 teachers of Junior High School Islamic Religion and Manner Education Teachers Subjects in Purwakarta District, with the following details:

- The need for Islamic Religion and Manner Education Teachers in SMP Negeri 1 Purwakarta, SMP Negeri 4 Purwakarta, SMP Negeri 5 Purwakarta, SMP Negeri 9 Purwakarta, and SMP Negeri 10 Purwakarta is sufficient.

- There is surplus each of 1 Islamic Religion and Manner Education Teacher at SMP Negeri 2 Purwakarta, SMP Negeri 3 Purwakarta, and SMP Negeri 8 Purwakarta.

- There is surplus each of 2 Islamic Religious and Manner Education Teachers in SMP Negeri 6 Purwakarta and SMP Negeri 7 Purwakarta.

8) The need of physical, sports and health education teachers: There are surplus of 8 Junior High School Physical, Sports and Health Education Subject Teachers in Purwakarta District, with the following details:

- The needs for Physical, Sports and Health Education Teachers at SMP Negeri 1 Purwakarta, SMP Negeri 3 Purwakarta, and SMP Negeri 4 Purwakarta are sufficient.

- There is surplus of 1 teacher of Physical, Sports and Health Education at SMP Negeri 2 Purwakarta, SMP Negeri 5 Purwakarta, SMP Negeri 7 Purwakarta, SMP Negeri 8 Purwakarta, SMP Negeri 9 Purwakarta, and SMP Negeri 10 Purwakarta.

- There are 2 more teachers of Physical, Sports and Health Education at SMP Negeri 6 Purwakarta.

9) The needs of pancasila and citizenship education teachers: There are surplus of 8 teachers of Junior High School Pancasila and Citizenship Subjects in Purwakarta District, with the following details: 
- The need for Pancasila and Citizenship Education Teachers at SMP Negeri 1 Purwakarta, SMP Negeri 3 Purwakarta, SMP Negeri 4 Purwakarta, SMP Negeri 5 Purwakarta, SMP Negeri 6 Purwakarta, SMP Negeri 7 Purwakarta and SMP Negeri 9 Purwakarta is sufficient.

- There is surplus each of 1 Pancasila and Citizenship Education Teacher at SMP Negeri 2 Purwakarta and SMP Negeri 10 Purwakarta.

- There are surplus of 2 Pancasila and Citizenship Education Teachers at SMP Negeri 8 Purwakarta.

10) The needs of craft teachers: As many as 5 Junior High School Craft Subject Teachers are needed in the Purwakarta District, with the following details:

- It takes 1 craft teacher each at SMP Negeri 1 Purwakarta, SMP Negeri 3 Purwakarta, SMP Negeri 4 Purwakarta, SMP Negeri 5 Purwakarta, SMP Negeri 7 Purwakarta, and SMP Negeri 9 Purwakarta.

- The need for craft teachers at SMP Negeri 2 Purwakarta, SMP Negeri 6, and SMP Negeri 10 Purwakarta is sufficient.

- There is surplus of 1 craft teacher at SMP Negeri 8 Purwakarta.

11) The needs of cultural arts teachers: There are surplus of 2 teachers of the State Junior High School Cultural Arts Subject in Purwakarta District, with the following details:

- The need for cultural arts teachers at SMP Negeri 1 Purwakarta, SMP Negeri 3 Purwakarta, SMP Negeri 4 Purwakarta, SMP Negeri 5 Purwakarta, SMP Negeri 6 Purwakarta, SMP Negeri 7 Purwakarta, and SMP Negeri 10 Purwakarta is sufficient.

- There is surplus of 1 person each at SMP Negeri 8 Purwakarta and 2 at SMP Negeri 2 Purwakarta.

- It takes 1 Teacher of Cultural Arts at SMP Negeri 9 Purwakarta.

\section{CONCLUSION AND SUGGESTION}

\section{A. Conclusion}

Education development has a very important role in increasing human resources. Teachers in the education process have a very central role. The proportional number and distribution of teachers is an absolute prerequisite for the achievement of development goals in the field of education.

The number of state junior high school teachers in Purwakarta District is 378 people, distributed in 10 schools in 6 sub-districts and 1 village. 10\% are in Cipaisan Sub-district, $30 \%$ are in Ciseureuh Sub-District, $7 \%$ are in Citalang Village, $11 \%$ are in Nagrikaler Sub-district, $11 \%$ are in Nagrikidul Subdistrict, 22\% are in Nagritengah Sub-district, and 9\% are in Sindangkasih Sub-district.
Based on the Basic and Secondary Education Process Standards as regulated in the Regulation of the Minister of Education and Culture Number 22 of 2016, the following data were obtained:

- There are surplus of 30 Indonesian Language Subject Teachers.

- There are surplus of 18 English Subject Teachers.

- There are surplus of 7 teachers of Islamic Religion and Manner Education Subjects.

- There are surplus of 8 teachers for Physical, Sports and Health Education Subjects.

- There are surplus of 4 teachers of Pancasila and Citizenship Education Subjects.

- There are surplus of 2 Teachers of Cultural Arts Subjects.

- The need for Natural Science Subject Teachers is 17 people.

- The need for Social Science Subject Teachers is 24 people.

- The need for Mathematics Teachers is 23 people.

- The need for Sundanese Subject Teachers (local content) is as many as 4 people.

\section{B. Suggestion}

This study has not described the real needs of subject teachers in Purwakarta district because the data used (teacher data and student data) are still within one year. Further research is needed with a broader component, including teacher qualifications, the suitability of a teacher's certificate with the subject being taught, and so on.

The needs of teachers for certain subjects can temporarily be overcome by hiring non-PNS teachers with appropriate qualifications so that they can be funded by budgets originating from the APBN (BOS) and funds sourced from the APBD. Another solution is the surplus distribution of subject teachers to be distributed to state junior high schools in need.

\section{ACKNOWLEDGMENT}

This work was supported by Indonesia University of Education, Bandung, Jawa Barat, Indonesia, and Purwakarta Regency Education Office.

\section{REFERENCES}

[1] Undang-Undang Nomor 17 Tahun 2007 tentang Rencana Pembangunan Jangka Panjang Nasional tahun 2005-2025.

[2] N. Sunuyeko, A. Lani and L. Wahyuni, "Analisis kebutuhan guru dalam pengimplementasian kurikulum 2013 di Sekolah Dasar," Sekolah Dasar: Kajian Teori dan Praktik Pendidikan, vol. 25, no. 1, pp. 18-26, 2017. 
[3] Peraturan Pemerintah Republik Indonesia Nomor 19 Tahun 2017 Tentang Guru.

[4] Keputusan Menteri Pemberdayaan Aparatur Negara Nomor KEP/75/M.PAN/7/2004 tentang Pedoman Perhitungan Kebutuhan Pegawai Berdasarkan Beban Kerja Dalam Rangka Penyusunan Formasi Pegawai Negeri Sipil.

[5] Peraturan Menteri Pendidikan dan Kebudayaan Republik Indonesia Nomor 22 Tahun 2016 tentang Standar Proses Pendidikan Dasar dan Menengah.
[6] S. Sugiyono and E. Wibowo, Statistik untuk penelitian. Bandung: Alfabeta, 2003.

[7] S. Syahrum and S. Salim, Metodologi Penelitian Kuantitatif, 2014.

[8] Undang-Undang Nomor 14 Tahun 2005 tentang Guru dan Dosen.

[9] Peraturan Daerah Kabupaten Purwakarta Nomor 1 Tahun 2019 tentang Rencana Pembangunan Jangka Menengah Daerah Tahun 2018-2023. 